\title{
Spatial variations and bioaccumulation of heavy metals in intertidal zone of the Yellow River estuary, China
}

\author{
Zhigao Sun a,b,*, Xiaojie Mou b,c, Chuan Tong a , Chuanyuan Wang ${ }^{\mathrm{b}, *}$, Zhenglei Xie ${ }^{\mathrm{d}}$, Hongli Song b,c, \\ Wenguang Sun ${ }^{\mathrm{b}}$, Yingchun $\mathrm{Lv}^{\mathrm{b}}$
}

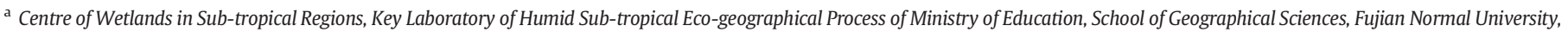
Fuzhou 350007, P. R. China

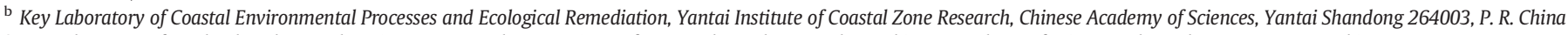

${ }^{\mathrm{c}}$ Key Laboratory of Wetland Ecology and Environment, Northeast Institute of Geography and Agroecology, Chinese Academy of Sciences, Changchun 130012, P. R. China

d Key Laboratory of Education Ministry for Poyang Lake Wetland and Watershed Research, College of Geography and Environment, Jiangxi Normal University, Nanchang 330022, P.R. China

\section{A R T I C L E I N F O}

\section{Article history:}

Received 7 June 2014

Received in revised form 26 October 2014

Accepted 31 October 2014

Available online 19 November 2014

\section{Keywords:}

Heavy metals

Sediments

Plants

Intertidal zone

Yellow River estuary

\begin{abstract}
A B S T R A C T
Nine units in new-born intertidal zone of the Yellow River estuary, China were examined for concentrations of heavy metals $(\mathrm{Pb}, \mathrm{Cr}, \mathrm{Cu}, \mathrm{Zn}$ and $\mathrm{Ni})$ in sediments and plants. Heavy metal levels in surface sediments were in the order of $\mathrm{Zn}>\mathrm{Pb} \approx \mathrm{Cr}>\mathrm{Cu} \approx \mathrm{Ni}$ and generally increased in a seaward direction except for $\mathrm{Z6}$ (Tamarix chinensis-Suaeda salsa zone) and Z7 (S. salsa-T. chinensis zone) units. Significant differences in metal concentrations of the 9 units were observed in the profiles $(p<0.01)$. Heavy metal levels in the shoots or roots of different plants decreased in the order of $\mathrm{Zn}>\mathrm{Cu}>\mathrm{Pb}>\mathrm{Ni}>\mathrm{Cr}$ and differed among plants or tissues. The roots at $\mathrm{Z2}$ (Calamagrostis pseudophragmites zone), Z3 (Imperata cylindrical zone) and Z4 (Phramites australis zone) units accumulated greater metals than shoots [TFs (translocation factors) $<1$ ], while the shoots at Z1 (Sparganium minimum-Potentilla supina zone), Z7 and Z8 (S. salsa zone) units accumulated greater metals than roots (TFs $>1$ ), implying that intertidal plants showed different pathways in metal accumulation and internal transportation. Except for $\mathrm{Pb}$, the concentrations of $\mathrm{Cr}, \mathrm{Cu}, \mathrm{Zn}$ and $\mathrm{Ni}$ in sediments were lower than the criteria of Class I recommended by the Environmental Quality Standard for Soils of China. Although heavy metal levels in intertidal zone were generally the lowest $(\mathrm{Cr}, \mathrm{Cu}, \mathrm{Zn}$ and $\mathrm{Ni}$ ) or relatively moderate $\mathrm{Pb})$ compared with other estuaries or bays in Asia and Europe, high eco-toxic risk of $\mathrm{Pb}$ and Ni exposure still could be observed at Z4, Z6 and Z9 (mudflat zone) units. S. salsa was more suitable for the potential biomonitor or phytoremediation of all five heavy metals if intertidal sediments was seriously contaminated with increasing of pollutants loading in the Yellow River estuary.
\end{abstract}

(c) 2014 Elsevier B.V. All rights reserved.

\section{Introduction}

Heavy metals are serious pollutants due to their toxicity, persistence in natural conditions and ability to be incorporated into food chains (Armitage et al., 2007; Sakan et al., 2009; Wang et al., 2013). Estuaries are zones of complex interaction between fluvial and marine processes that may act as a geochemical trap for heavy metals bonded in the sediments. The mixing of continental river water and marine salt water usually leads to flocculation and accumulation processes of heavy metals, which are mainly controlled by water/particle interactions and solution chemistry, such as sedimentation, flocculation, organic and inorganic complexation, adsorption and sediment resuspension (Flegal et al., 1991; Moran et al., 1996). In addition, evolution of the composition of the particle in the mixing zone of the estuary indicates that heavy metals do not behave conservatively and that they are also

\footnotetext{
* Corresponding authors at: Fujian Normal University, Fuzhou 350007, China.

E-mail addresses: zgsunyic@126.com (Z. Sun), cywang@yic.ac.cn (C. Wang).
}

affected by the changing physico-chemical conditions, such as salinity, pH and redox (Calmano and Hong, 1993; Comans and van Dijk, 1988). Heavy metals released into coastal marsh are generally bound to particulate matter, which eventually settle down and be incorporated into sediments. Marsh plants can take up large quantities of sedimentbound metals, releasing them as they decay (Baldantoni et al., 2004). In general, factors affecting metal accumulation by plants can be biological (e.g., species, growth stage, generation) and non-biological (e.g., temperature, season, salinity, $\mathrm{pH}$, metal concentration) (Bonanno and Giudice, 2010). In recent years, there has been an ever-increasing interest in discussing the fate of heavy metals in coastal marshes (Comans and van Dijk, 1988; Griscom et al., 2000; Turner, 2000) and the metal-accumulation plants for environmental remediation application (termed as 'phytoremediation') (Chaney et al., 1997; Deng et al., 2004; Peng et al., 2008). Previous studies have showed that coastal marshes were generally recognized to be important reservoirs or sinks as filters, retaining heavy metals that exist in water, sediments, plants and other organisms (Arias et al., 2005; Prokisch et al., 2009). The 
heavy metals retained in marsh may also have significantly toxic effects on wildlife (Zhang et al., 2010a). Thus, studies on distribution and geochemical behavior of heavy metals in sediments and plants are significant for interpreting the geochemistry of heavy metals in the estuaries and elucidating the physical, chemical and biological processes that happen between the land and the ocean (Wang and Liu, 2003).

The Yellow River is the second largest river in China and is well known as a sediment-laden river in the world. In recent years, approximately $1.68 \times 10^{8}$ tons of sediment is carried to the estuary and deposited in the slow flowing delta, which forms an extensive intertidal zone and special marsh landscape (Xu et al., 2002). Meanwhile, approximately $4.40 \times 10^{5}$ tons of pollutants (including 1,110 tons of heavy metals) from the cities and industrial and mining enterprises in the Yellow River basin were carried to the estuary (State Oceanic Administration of China, 2013). Presently, the Yellow River Delta is an important economic development area in Shandong Province of China. With the rapid development of industrialization, urbanization and agricultural practices in the coastal zone of the Yellow River Delta, the ecological health of estuarine ecosystem are threatening by loading excessive pollutants (especially threatened by heavy metals) (Tang et al., 2010). The coastal marsh in the Yellow River estuary is predominantly composed of silts and clayey silts, reflecting the fact that the suspended materials discharging into the estuarine region are dominated by fine grained particles (about $73.6 \%$ is $<32 \mu \mathrm{m}$ during flood season) (Deng et al., 2008). The plants in the coastal marsh also contribute to the spatial distribution of sediment grain size due to the influence of vegetation in attenuating tide energy (Yang, 1999). Previous studies have showed that particle size significantly influenced the fate and accumulation of heavy metals in coastal marsh sediments (Breslin and Sanudo-Wilhelmy, 1999; Gao and Li, 2012; Zhang et al., 2001, 2011). Fine grained sediments often show higher concentrations of heavy metals due to their greater surface to volume ratio and enrichment of organic matter and Fe-Mn oxides (Rae, 1997; Williams et al., 1994), but how the sediment grain-size influences the spatial distribution of heavy metals in marsh sediments of the Yellow River estuary remains scarce. Since coastal marshes are generally recognized as an important filter for retaining heavy metals, the distribution, variation and transportation of the heavy metals in sediments and plants, to a great extent, affects the accumulation and chronic poisoning of wild animals or human by food chains (Prokisch et al., 2009; Tang et al., 2010). However, insufficient information is available in the Yellow River estuary concerning the distribution of heavy metal concentrations in sediments and plants and the abilities of different plants or tissues to absorb and transport metals. Understanding the related knowledge will provide insight into choosing suitable plants for marsh phytoremediation systems in the future.

In this paper, heavy metal concentrations ( $\mathrm{Pb}, \mathrm{Cr}, \mathrm{Cu}, \mathrm{Zn}$ and $\mathrm{Ni}$ ) in intertidal zone of the Yellow River estuary were determined by in situ sampling and ICP-MS (Inductively coupled plasma mass spectrometry) analysis. The primary objectives of this study were $i$ ) to investigate the spatial distribution of heavy metals in sediments across the intertidal zone, (ii) to determine the differences in heavy metal levels accumulated by shoots or roots of different intertidal plants, and (iii) to discuss the potential use of intertidal plants for biomonitor or phytoremediation.

\section{Study area and methods}

\subsection{Study area}

This study was carried out in intertidal zone of the northern Yellow River estuary, which is located in the Nature Reserve of the Yellow River Delta $\left(37^{\circ} 35^{\prime} \mathrm{N} \sim 38^{\circ} 12^{\prime} \mathrm{N}, 118^{\circ} 33^{\prime} \mathrm{E} \sim 119^{\circ} 20^{\prime} \mathrm{E}\right)$ in Dongying City, Shandong Province, China. Both tides and waves influence sediment transportation and accumulation in intertidal zone. The tide in intertidal zone is irregular semidiurnal tide and the mean tidal range is 0.73-1.77 $\mathrm{m}$ (Li et al., 1991). Under fair weather conditions, the Yellow River estuary coast is less influenced by waves and tides play the dominant role in controlling sedimentation in intertidal zone. Coastal marsh is the main marsh type, with an area of $964.8 \mathrm{~km}^{2}$, accounting for $63.06 \%$ of the total area of the Yellow River Delta (Cui et al., 2009). The marsh soil is dominated by salt soil and the main marsh vegetations include Suaeda salsa, Phragmites australis and Tamarix chinensis (Sun et al., 2013; Tian et al., 2005). The width of the coastal marsh in the Yellow River estuary ranged from $4 \mathrm{~km}$ to $>10 \mathrm{~km}$, and from the land to the sea, a well-developed intertidal zone typically contains 9 distinct units (Fig. 1): a Sparganium minimum and Potentilla supina zone (S. minimum is dominant species, Z1), a Calamagrostis pseudophragmites zone (Z2), a Imperata cylindrical zone (Z3), a P. australis zone (Z4), a S. salsa and $P$. australis zone ( $S$. salsa is dominant species, Z5), a $T$. chinensis and $S$. salsa zone ( $T$. chinensis is dominant species, Z6), a S. salsa and T. chinensis zone ( . salsa is dominant species, Z7), a pure S. salsa zone (Z8) and mudflat zone (Z9). The aboveground and belowground biomasses of the plants in intertidal zone are shown in Fig. 2 (Dong et al., 2010). This sequence of geomorphic units is complete in intertidal zone of the Yellow River estuary due to less human activities, which generally comprises three areas in a seaward direction: high marsh (Z1, Z2, Z3 and Z4), middle marsh (Z5, Z6 and Z7 units) and low marsh ( $Z 8$ and $Z 9$ ), at the elevations of $2.4-3.5 \mathrm{~m}, 1.0-2.5 \mathrm{~m}$ and $-1.0-0.9 \mathrm{~m}$, respectively (Song et al., 2010). The physical and chemical properties of topsoil $(0-10 \mathrm{~cm})$ in high marsh, middle marsh and low marsh are shown in Table 1.

\subsection{Study methods}

\subsubsection{Sample collection}

Two typical transects perpendicular to the riverbank or extending from the vegetated marsh zones to the mudflat were laid in intertidal zone of the northern Yellow River estuary in May 2009. On each transect, the surface and profile samples were taken at the abovementioned Z1, Z2, Z3, Z4, Z5, Z6, Z7, Z8 and Z9 zones, respectively. At each zone, 4 surface samples were collected at a sampling depth of $0-5 \mathrm{~cm}$ and 2 profiles $(0-60 \mathrm{~cm})$ were simultaneously sampled at $10 \mathrm{~cm}$ interval. A total of 72 surface samples and 216 profile samples were collected. All sediment samples were air-dried, ground and sieved through a 100-mesh nylon sieve. Aboveground and belowground biomasses of plants ( 3 replications) were collected from the same position with sediment profile samples, with 96 samples in total. All plant samples were washed thoroughly with deionized water and then oven-dried at $80{ }^{\circ} \mathrm{C}$ for $48 \mathrm{~h}$. After the measurement of dry weights, the samples were ground into fine powder $(<0.25 \mathrm{~mm})$.

\subsubsection{Sample analysis}

A $0.1000 \mathrm{~g}$ homogenized sediment sub-sample was digested with $2 \mathrm{~mL} \mathrm{HNO}_{3}, 1 \mathrm{~mL} \mathrm{HClO}_{4}$ and $5 \mathrm{~mL} \mathrm{HF}$ at $160-190^{\circ} \mathrm{C}$ for $16 \mathrm{~h}$. The residue was dissolved in $2 \mathrm{~mL}$ of $4 \mathrm{~mol} / \mathrm{L} \mathrm{HCl}$ and then diluted to $10 \mathrm{~mL}$ with deionized water for heavy metal analysis. A $0.2000 \mathrm{~g}$ plant sub-sample was digested in a mixture of $65 \% \mathrm{HNO}_{3}(2 \mathrm{~mL})$ and $30 \% \mathrm{H}_{2} \mathrm{O}_{2}(1 \mathrm{~mL})$. The residue was diluted with deionized water to $10 \mathrm{~mL}$ for analyzing heavy metal concentrations. The concentrations of heavy metals $(\mathrm{Pb}, \mathrm{Cr}, \mathrm{Cu}$, $\mathrm{Zn}$ and $\mathrm{Ni}$ ) in all samples were determined by Agilent 7500 ICP-MS (Agilent Company, America). Quality assurance and quality control were assessed using duplicates, method blanks and standard reference materials (GBW07401 and GBW08513) from the National Research Center for Standards in China with each batch of samples (one blank and one standard for each 20 samples). Sediment organic matter (SOM) was measured by $\mathrm{K}_{2} \mathrm{Cr}_{2} \mathrm{O}_{7}$ oxidation method (The Committee of Agro-chemistry of the Chinese Society of Soil Science, 1983). Moreover, 54 samples from the 9 units were selected for grain-size determination using Coulter Laser granulometer.

\subsubsection{Calculations}

To study the accumulation and transportation characteristics of heavy metals in plants, the bioaccumulation factor (BCF) and translocation 


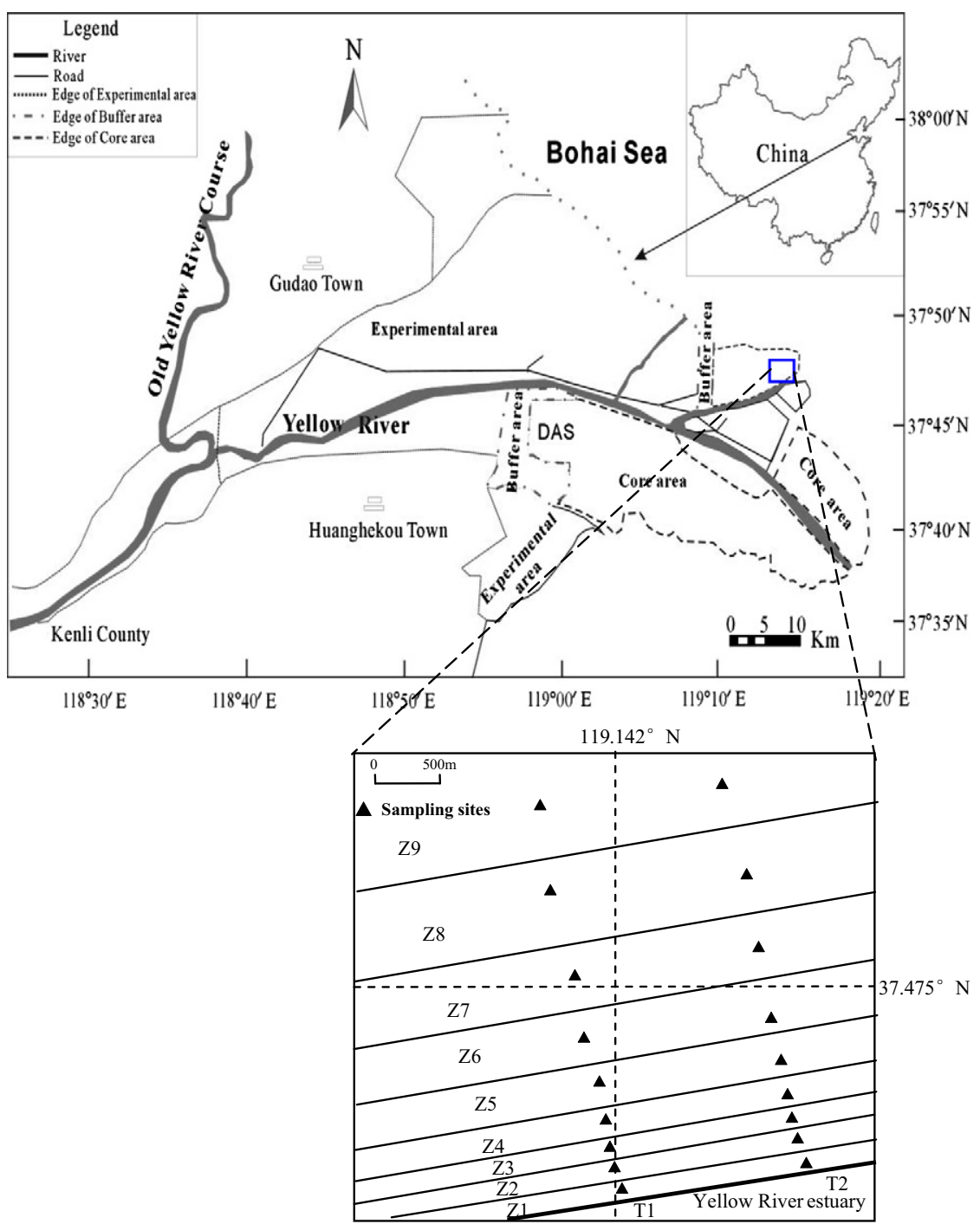

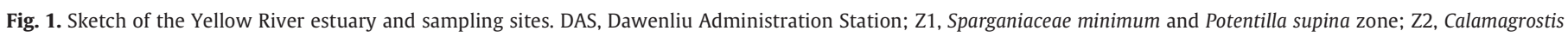

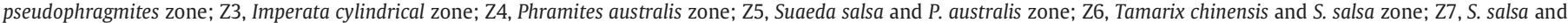
T. chinensis zone; Z8, S. salsa zone; Z9: mudflat; T1, Transect 1 ; T2, Transect 2 . The same below.

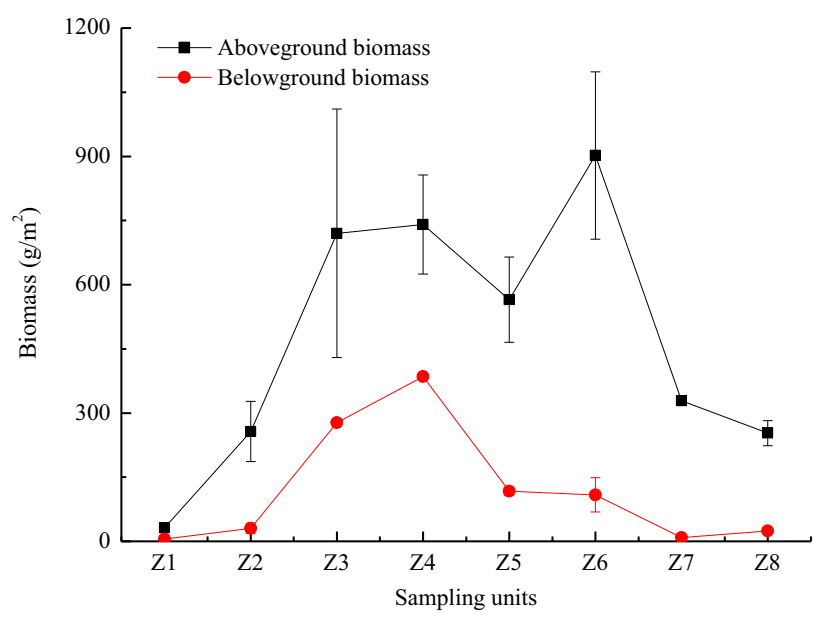

Fig. 2. Aboveground and belowground biomasses of the plants in intertidal zone of the Yellow River estuary. factor (TF) of different plants were calculated by Eqs. (1) and (2), respectively (Zhang et al., 2011).

$\mathrm{BCF}=C_{\text {plant }} / C_{\text {sediment }}$

where, $C_{\text {plant }}$ and $C_{\text {sediment }}$ are the average metal concentrations in plants and sediments, respectively.

$\mathrm{TF}=C_{\text {shoot }} / C_{\text {root }}$

where, $C_{\text {shoot }}$ and $C_{\text {root }}$ are the average metal concentrations in shoots and roots of plants, respectively.

\subsubsection{Statistical analysis}

Statistical analysis of experimental data was performed using SPSS Version 11.0 Statistical Software Package (SPSS Inc., Chicago, U.S.A.). The means of the replicates and the evaluation of significant differences 
Table 1

Physical and chemical properties of topsoil $(0-10 \mathrm{~cm})$ in high marsh, middle marsh and low marsh ${ }^{\mathrm{a}}$.

\begin{tabular}{|c|c|c|c|c|c|c|c|}
\hline Marshes & $\begin{array}{l}\text { Bulk density } \\
\left(\mathrm{g} / \mathrm{cm}^{3}\right)\end{array}$ & $\mathrm{pH}$ & $\begin{array}{l}\text { Soil moisture } \\
\left(\mathrm{cm}^{3} / \mathrm{cm}^{3}\right)\end{array}$ & $\begin{array}{l}\text { Electrical conductivity } \\
(\mathrm{mS} / \mathrm{cm})\end{array}$ & $\begin{array}{l}\text { Total nitrogen } \\
(\mathrm{mg} / \mathrm{kg})\end{array}$ & $\begin{array}{l}\text { Total phosphorus } \\
(\mathrm{mg} / \mathrm{kg})\end{array}$ & $\begin{array}{l}\text { Total Sulfur } \\
(\mathrm{mg} / \mathrm{kg})\end{array}$ \\
\hline High marsh & $1.28 \pm 0.08$ & $7.90 \pm 0.05$ & $0.302 \pm 0.009$ & $3.58 \pm 1.48$ & $408.38 \pm 96.69$ & $506.59 \pm 20.72$ & $305.17 \pm 67.37$ \\
\hline Middle marsh & $1.33 \pm 0.03$ & $8.55 \pm 0.06$ & $0.289 \pm 0.013$ & $5.58 \pm 2.80$ & $455.90 \pm 162.07$ & $521.09 \pm 49.91$ & $420.11 \pm 33.05$ \\
\hline Low marsh & $1.64 \pm 0.03$ & $8.86 \pm 0.04$ & $0.346 \pm 0.031$ & $18.07 \pm 0.43$ & $505.45 \pm 70.22$ & $527.32 \pm 10.69$ & $466.26 \pm 100.54$ \\
\hline
\end{tabular}

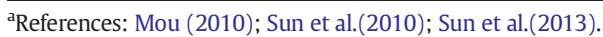

among sampling units or plants were determined by descriptive statistics and analysis of variance (ANOVA), respectively. Correlations between heavy metal concentrations and grain-size (or SOM) were evaluated using Pearson correlation coefficients.

\section{Results}

\subsection{Grain-size and SOM in different sediments}

Particle-size analysis revealed a predominance of silt (4-63 $\mu \mathrm{m})$ in sediments across the intertidal zone, accounting for $76-80 \%$ of the particles at Z3, Z4, Z5, Z6, Z8 and Z9 units and more than $80 \%$ of the particles at Z1, Z2 and Z7 units (Fig. 3$)$. The clay particle $(<4 \mu \mathrm{m})$ of surface sediment was relatively low, with the values of less than $10 \%$ from $\mathrm{Z} 1$ to $\mathrm{Z7}$ units and only $16-21 \%$ at Z8 and Z9 units. The surface sediment grains tended to become fine moving from the land to the sea as demonstrated by a decrease in sand fraction together with an increase in clay fraction. The grain-size distribution in the profiles showed a tendency for the grains to become coarse in a seaward direction (Fig. 4) - i.e. an increasing sand fraction and a decreasing clay fraction were observed moving from Z1 to Z9 units. Silt dominated over all profiles and the values ranged from $57 \%$ to $88 \%$. Little vertical variations of grain-size occurred at Z3, Z5, Z6, Z8 and Z9 units, while great changes were observed at Z1, $\mathrm{Z2}, \mathrm{Z4}$ and $\mathrm{Z7}$ units. Significant differences in SOM content of the 9 units were observed in the profiles ( $p<0.01$ ) (Fig. 5). The SOM in surface sediment of Z7 unit was significantly lower compared to other units $(p<0.05)$. With increasing depth, higher values were observed in 30-50 cm depth at Z4 and Z7 units.

\subsection{Heavy metal distributions in different sediments}

\subsubsection{Distributions in the surface sediments}

The concentrations of heavy metal in surface sediments of the intertidal zone were generally in the order of $\mathrm{Zn}>\mathrm{Pb} \approx \mathrm{Cr}>\mathrm{Cu} \approx \mathrm{Ni}$ (Fig. 6). Variations of $\mathrm{Cu}, \mathrm{Zn}$ and Ni concentrations were similar in a seaward direction, with the maximums occurring at $Z 9$ units. Although similar

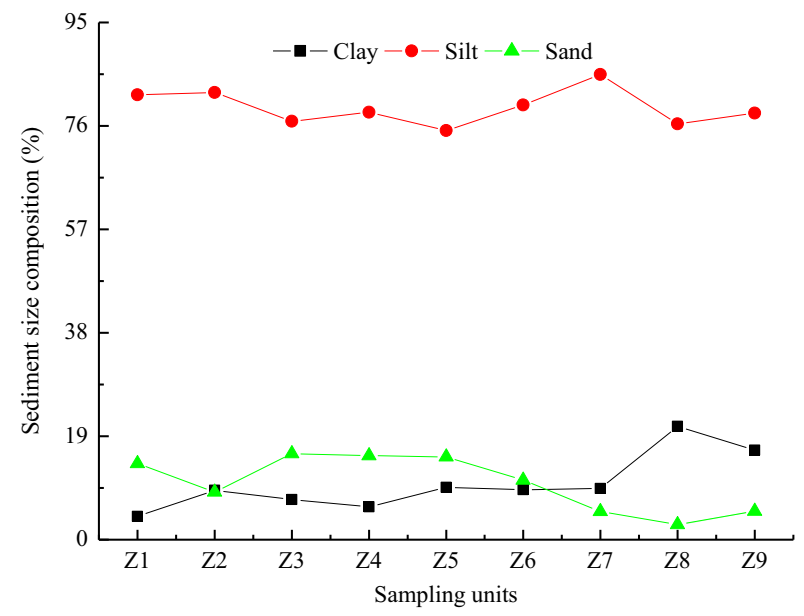

Fig. 3. Grain-size distribution in surface sediments. variations of $\mathrm{Pb}$ and $\mathrm{Cr}$ concentrations were observed within the intertidal zone, the highest values occurred at Z8 and Z9 units, respectively. Heavy metal concentrations generally increased from the land to the sea except for Z6 and Z7 units. The values at Z9 unit were approximately 32.0-66.2\% higher than those at Z1 unit.

\subsubsection{Vertical distributions in the profiles}

Significant differences in heavy metal concentrations of the 9 units were observed in the profiles $(p<0.01)$ (Fig. 5). The Pb concentrations at Z1 and Z5 units decreased with increasing depth, while those at Z2, Z3, Z6, Z8 and Z9 units decreased at $0-30 \mathrm{~cm}$ depth and fluctuated greatly at 30-60 cm depth. The $\mathrm{Cr}$ concentrations at $\mathrm{Z} 2$ and $\mathrm{Z} 3$ units, or the $\mathrm{Cu}$ and $\mathrm{Ni}$ concentrations at $\mathrm{Z} 1$ and $\mathrm{Z3}$ units, or the $\mathrm{Zn}$ concentrations at Z1, Z3 and Z8 units also decreased with increasing depth, while at other units, the $\mathrm{Cr}, \mathrm{Cu}, \mathrm{Zn}$ and $\mathrm{Ni}$ concentrations showed different vertical variations. The highest concentrations of all five heavy metals were observed in 30-50 cm depth at Z4 unit (Fig. 5).

\subsection{Heavy metal distributions in different plants}

The concentrations of heavy metal in the shoots or roots of different plants generally decreased in the order of $\mathrm{Zn}>\mathrm{Cu}>\mathrm{Pb}>\mathrm{Ni}>\mathrm{Cr}$ (Fig. 7). The highest values of $\mathrm{Pb}, \mathrm{Cr}, \mathrm{Cu}, \mathrm{Zn}$ and $\mathrm{Ni}$ in shoots were observed at $\mathrm{Z1}$ unit. Except for Z1 unit, the concentrations of heavy metal in the shoots of different plants generally increased from the land to the sea (Fig. 7a). The highest concentrations of $\mathrm{Zn}, \mathrm{Cu}$ and $\mathrm{Pb}$ in roots also occurred at $\mathrm{Z1}$ unit while those of $\mathrm{Ni}$ and $\mathrm{Cr}$ were observed at $\mathrm{Z} 2$ unit. From $\mathrm{Z} 3$ to Z8 units, $\mathrm{Zn}$ and $\mathrm{Cu}$ concentrations in the roots of different plants fluctuated greatly compared to $\mathrm{Pb}, \mathrm{Cr}$ and $\mathrm{Ni}$ (Fig. 7b). The BCFs of $\mathrm{Zn}$ and $\mathrm{Cu}$ in different plants obtained from 8 units were higher than those of $\mathrm{Pb}, \mathrm{Cr}$ and $\mathrm{Ni}$ (Fig. 8). The highest $\mathrm{BCFs}$ of $\mathrm{Pb}, \mathrm{Cr}, \mathrm{Cu}$ and $\mathrm{Zn}$ were observed at $\mathrm{Z} 1$ unit while that of $\mathrm{Ni}$ occurred at $\mathrm{Z7}$ unit. The TFs of all five metals at Z1 unit were very high while those at other units generally increased from the land to the sea. The highest TFs of $\mathrm{Pb}, \mathrm{Cr}$, $\mathrm{Cu}$ and $\mathrm{Zn}$ occurred at Z8 unit while that of Ni was observed at Z7 unit (Fig. 8).

\section{Discussion}

\subsection{Distribution of heavy metals in sediments}

The concentrations of heavy metal in sediments were generally related to pollutant inputs, physical characteristics (e.g., grain-size) and the chemical conditions of the sedimentary environment (Williams et al., 1994). In this study, the inter- and intra-sites variability of heavy metal levels in intertidal zone appeared to be influenced by these factors, but the significance of each of these factors varied among 9 units. Influence of metal input was clearly observed by higher heavy metal concentrations at Z8 and Z9 units. Presently, the heavy metal loading of the Yellow River estuary is increasing due to human activities (State Oceanic Administration of China, 2013) and approximately 1,110 tons of heavy metals were discharged into Bohai Sea in 2012, which increased by $59.5 \%$ and $73.4 \%$ compared to 2010 and 2011, respectively (State Oceanic Administration of China, 2011, 2012, 2013). These heavy metals could be mixed with seawater or sediments near the estuary and had significant influences on the metal concentrations in sediments of low marsh by tidal fluctuation. Although the middle marsh 

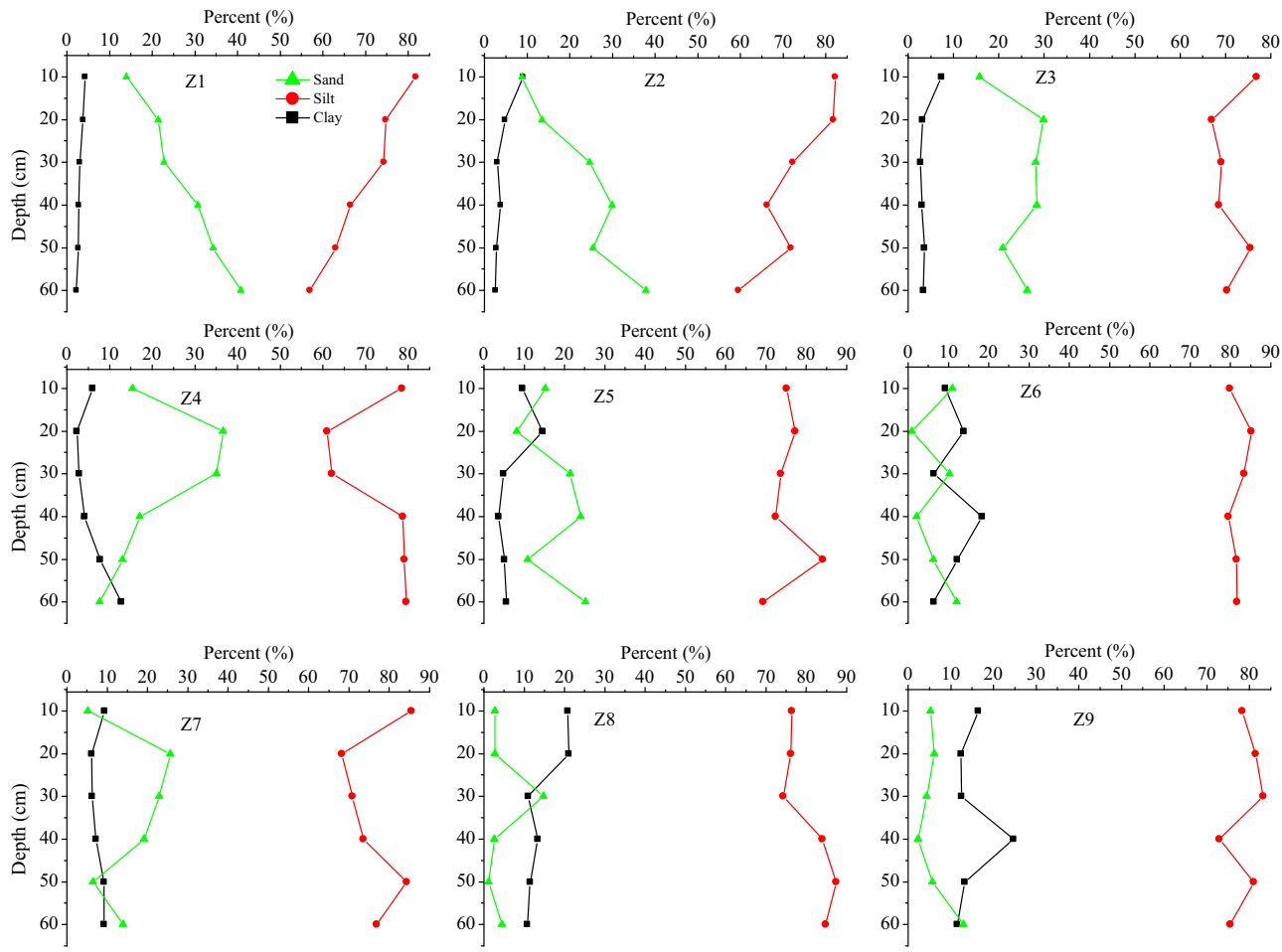

Percent (\%)

Percent (\%)
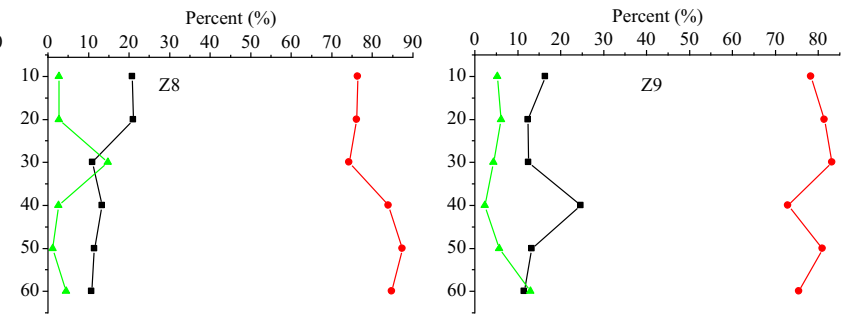

Fig. 4. Grain-size distribution in the profiles.
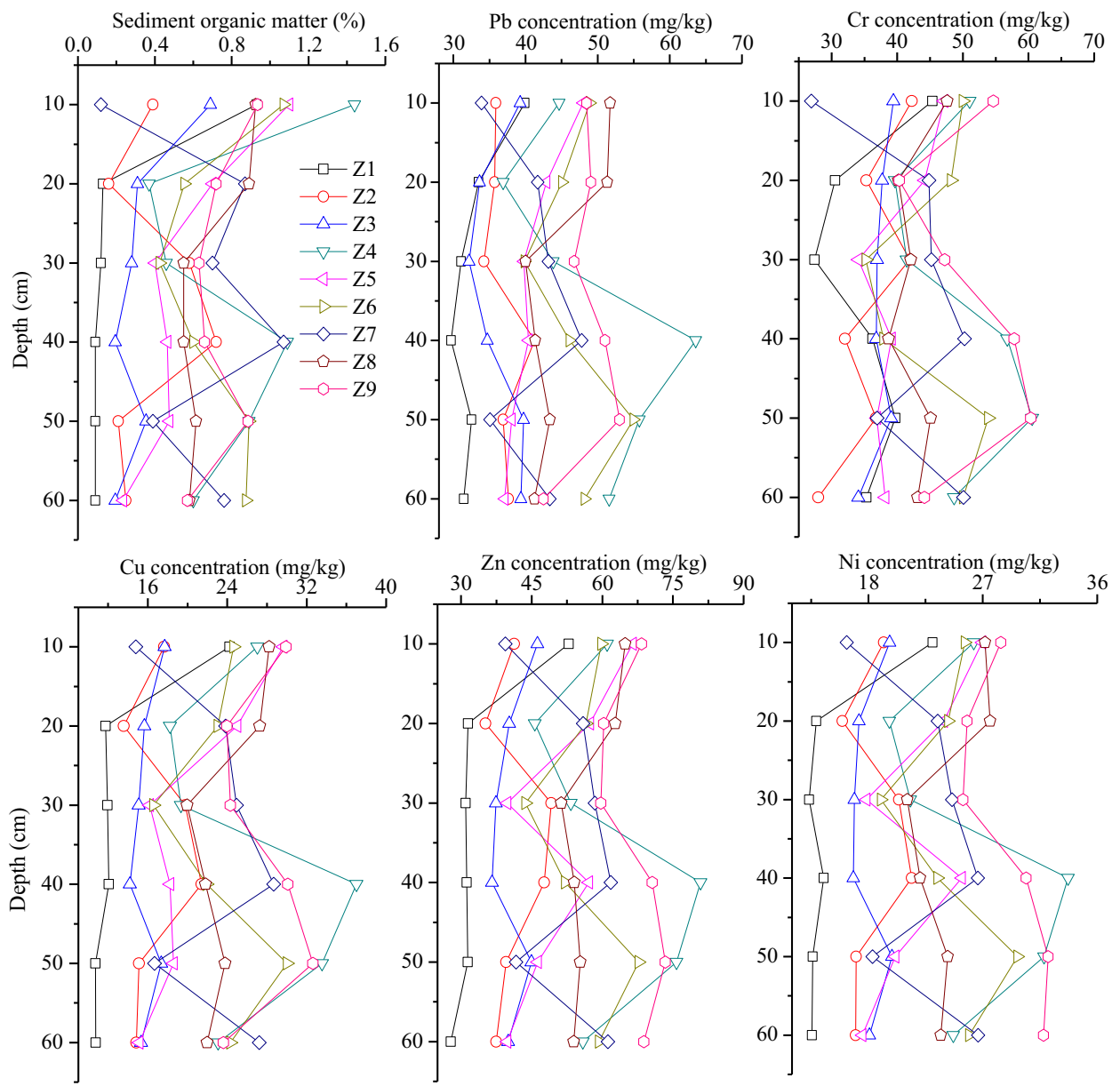

Fig. 5. Vertical distributions of sediment organic matter (SOM) and heavy metal concentrations in the profiles. 


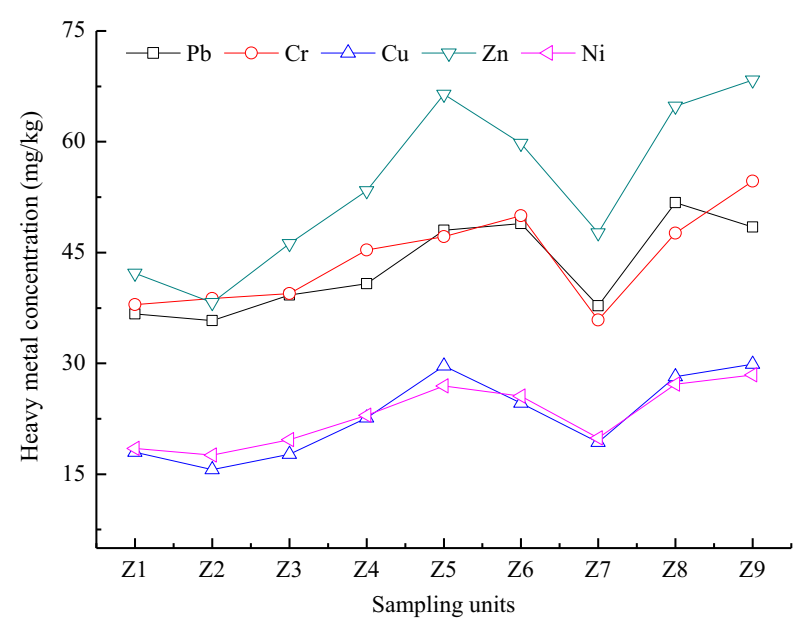

Fig. 6. Heavy metal distributions in the surface sediments.

was also greatly affected by tidal fluctuation, the very low concentrations of heavy metal in surface sediment of $Z 7$ unit were observed across the intertidal zone (Fig. 6). Previous studies indicated that topography significantly affected metal mobility and availability (Bockheim, 2005; Du Laing et al., 2009; Zhang et al., 2011). The sites that were subjected to intensive tidal washing generally had lower metal concentrations, while those subjected to relatively lower water flow facilitated the deposition of metal particles (Mistch et al., 2009). Because Z7 unit was located in the transitional zone of middle marsh and low marsh, the lower
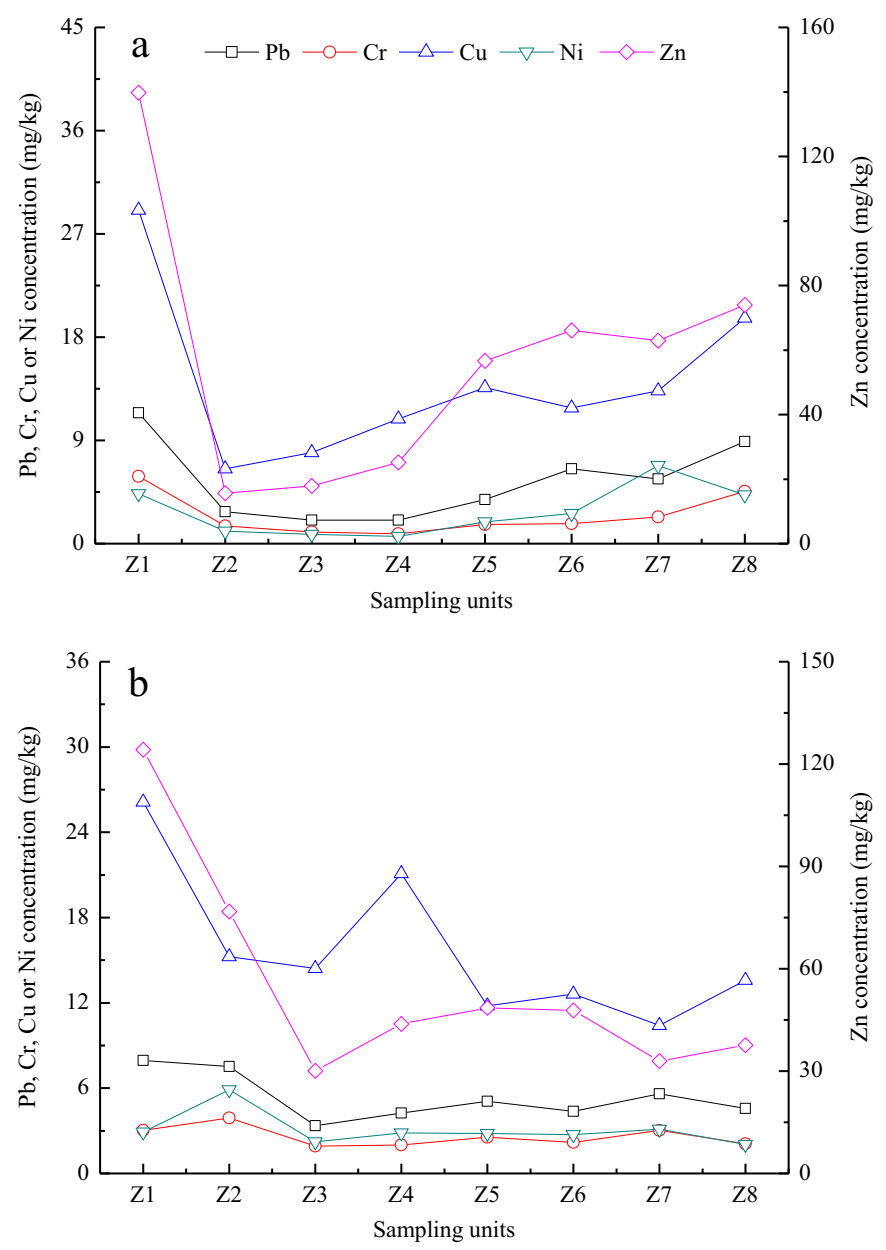

Fig. 7. Heavy metal distributions in the shoots (a) and roots (b) of different plants. heavy metal concentrations in surface sediment were mainly correlated with their strong mobility in the profiles. In the transitional zone, the gradient of topography generally decreased and the movement of water in sediment greatly enhanced, which was favorable for the mobility of heavy metals. Accompanied by strong mobility of water in sediment, the salinity in water could also promote heavy metal mobility through complexation with salt anions and ion exchange between the cations and the metal ions (Du Laing et al., 2008; Li et al., 2011). These explanations could be demonstrated by the similar distributions of all five metals in the profile of $\mathrm{Z7}$ unit and the great increase in metal concentrations at depth of 20-40 cm (Fig. 5). Except for Z6 and Z7 units, heavy metal concentrations in surface sediments in a seaward direction generally increased, reflecting the joint influences of pollutant inputs and tidal fluctuation on the distributions of heavy metals across the intertidal zone.

In addition to metal inputs, sediment grain-size and SOM play significant role in the accumulation of heavy metals in sediment across the intertidal zone (Xu et al., 1997). Higher levels of heavy metal occur in relatively fine-grained sediments and SOM generally acts as a major sink for metals due to its strong complexing capacity (Du Laing et al., 2009). This was tested in our study. Pearson correlation analysis indicated that significantly positive correlations were observed between clay fraction (or SOM) and heavy metal concentrations over all sampling units ( $p<0.001)$ (Fig. 9). The higher concentrations of heavy metal in surface sediments of Z8 and Z9 units corresponded well to an increase in clay fraction in these sediments (Figs. 3, 6). In the surface sediment of $\mathrm{Z7}$ unit, the clay fraction approximated $10 \%$ and the silt fraction was the highest (85.5\%) (Fig. 3), but the heavy metal concentrations were very low (Fig. 6). For one thing, the reason was due to the joint influences of topography, water movement and salinity at $Z 7$ unit, which was analyzed previously. For another, it was dependent on the SOM content in surface sediment of Z7 unit. As mentioned previously, significantly lower SOM content was observed in surface sediment of Z7 unit compared to other units $(p<0.05)$ (Fig. 5). The lowest SOM content generally reduced its complexing capacity for heavy metals, which was unfavorable for the conservation of metals (Zhang et al., 2011). Moreover, the vertical distributions of SOM at some units were similar with those of five heavy metals. Especially, both SOM and heavy metals reached the higher values in 30-50 cm depth at Z4 unit (Fig. 5), implying the great influence of SOM on the accumulation of heavy metals in the profile.

This study also showed that the concentrations of $\mathrm{Cr}, \mathrm{Cu}, \mathrm{Zn}$ and $\mathrm{Ni}$ in sediments sampled from 9 units were lower than the criteria of Class I ( $\mathrm{Cr} \leq 90 \mathrm{mg} / \mathrm{kg}, \mathrm{Cu} \leq 35 \mathrm{mg} / \mathrm{kg}, \mathrm{Zn} \leq 100 \mathrm{mg} / \mathrm{kg}, \mathrm{Ni} \leq 40 \mathrm{mg} / \mathrm{kg}$ ) recommended by the Environmental Quality Standard for Soils of China (EQSS) (GB 15618-1995), while those of Pb mostly exceeded the maximum permitted limit of Class I ( $\mathrm{Pb} \leq 35 \mathrm{mg} / \mathrm{kg}$ ) in EQSS (Figs. 5-6). According to the eco-toxic threshold values established by the U.S. Environmental Protection Agency in the sediment (U.S. EPA, 1996), most investigated sediments at Z4, Z6 and Z9 units slightly exceeded the upper limits for $\mathrm{Pb}(47 \mathrm{mg} / \mathrm{kg}$ ), whilst those at $\mathrm{Z4}, \mathrm{Z6}, \mathrm{Z8}$ and $Z 9$ units were 1.01-1.61 folds higher than the upper limits for $\mathrm{Ni}$ $(21 \mathrm{mg} / \mathrm{kg}$ ) (Fig. 5). Those indicated that the intertidal zone in the Yellow River estuary, especially for Z4, Z6 and Z9 units, had high ecotoxic risk of $\mathrm{Pb}$ and $\mathrm{Ni}$ exposure. In comparison to the heavy metal levels of intertidal sediments reported from other estuaries or bays in Asia and Europe, the levels of $\mathrm{Cr}, \mathrm{Cu}, \mathrm{Zn}$ and $\mathrm{Ni}$ in intertidal sediments of the Yellow River estuary were generally the lowest, while that of $\mathrm{Pb}$ was relatively moderate (Table 2 ). This related to the large volume of runoff discharge (19.3 billion $\mathrm{m}^{3}$ in average) and sediments $\left(1.68 \times 10^{8}\right.$ tons in average) carried by the Yellow River, which had a significant dilution effect on the loadings of pollutant. In addition, the intertidal zone of the Yellow River estuary was located in the core protection area of the Yellow River Delta National Nature Reserve and was formed since the Yellow River changed its tail channel in Qingbacha in 1996 (Chang et al., 2004). The new-born intertidal zone was only subjected to a 


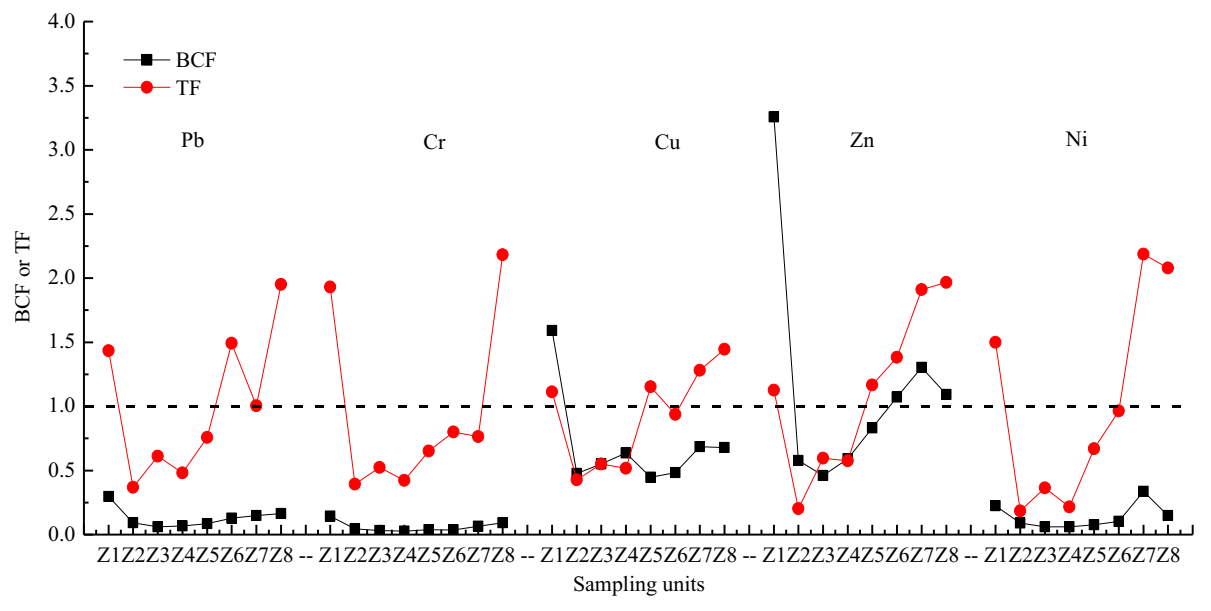

Fig. 8. Bioaccumulation factors (BCFs) and translocation factors (TFs) of heavy metals in different plants.

short period of effects of pollutant inputs since the 2000s. As mentioned previously, the heavy metal loading of the Yellow River estuary is increasing due to intensive human activities. Thus, the juxtaposition of pollution sources and the silt-rich nature of the waters into which discharges are made means that there will be long-term potential consequences for the intertidal zone of the Yellow River estuary if measures are not taken to control the loading of pollutants in the future.
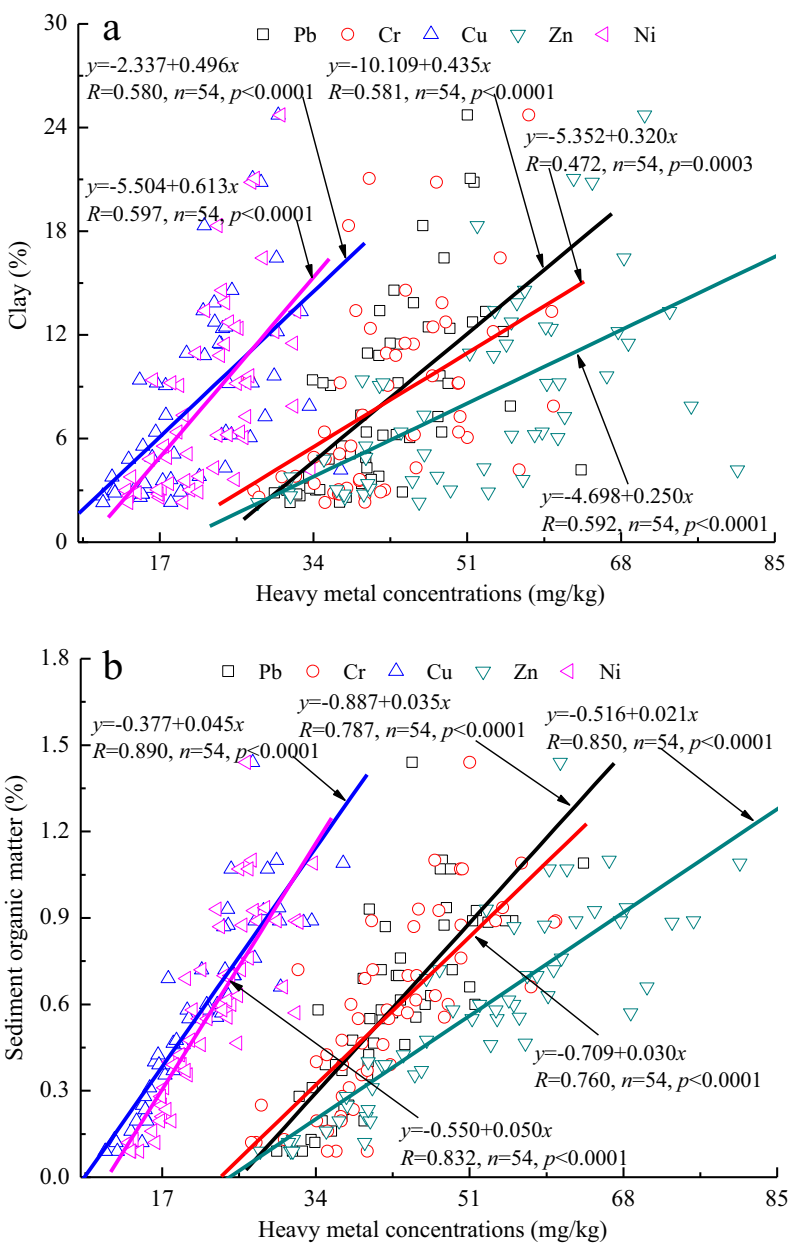

Fig. 9. Scatter plots of heavy metal concentrations against clay (a) or sediment organic matter (b) across the intertidal zone.

\subsection{Distribution of heavy metals in plants}

This study showed that trace metal concentrations not only differed among plants but also varied between tissues (Fig. 7). Similar results were drawn by many previous studies (Baldantoni et al., 2004; Bonanno and Giudice, 2010; Demirezen and Aksoy, 2004; Deng et al., 2004; Peng et al., 2008; Zhang et al., 2011). Pb is not essential in plant organisms and can prove toxic. Pb concentrations found in the shoots and roots of all sampling plants ranged from 2.04 to $11.40 \mathrm{mg} / \mathrm{kg}$ and from 3.36 to $7.95 \mathrm{mg} / \mathrm{kg}$, respectively, which were far lower than the phytotoxic range (30-300 mg/kg) presented by Ross (1994). Cr is an element regarded as toxic for plants. According to Allen (1989), $\mathrm{Cr}$ concentrations greater than $0.5 \mathrm{mg} / \mathrm{kg}$ were toxic to plants. In this study, all shoots and roots presented $\mathrm{Cr}$ values $(0.85-5.87 \mathrm{mg} / \mathrm{kg}$ and $2.01-3.90$ $\mathrm{mg} / \mathrm{kg}$, respectively) above the phytotoxic threshold (Fig. 7), indicating that intertidal plants showed serious $\mathrm{Cr}$ contamination. $\mathrm{Cu}$ is vital for plant nutrition and needed for various enzymatic activities of oxidation-reduction (Bonanno and Giudice, 2010). However, under long-term exposure, high Cu concentrations may affect root energy metabolism (Fürtig et al., 1999) and will cause toxic effects as the concentrations in plants greater than $15-20 \mathrm{mg} / \mathrm{kg}$ (Kabata-Pendias and Pendias, 2001). In this study, the majority of Cu concentrations in intertidal plants were below or close to $20 \mathrm{mg} / \mathrm{kg}$ except the values in the shoots and roots of S. minimum-P. supina at Z1 unit $(29.08 \mathrm{mg} / \mathrm{kg}$ and $26.13 \mathrm{mg} / \mathrm{kg}$, respectively), indicating that Cu contamination was generally not serious in intertidal plants. $\mathrm{Zn}$ plays an important role in plant nutrition and enzymatic activities (Bonanno and Giudice, 2010). The average concentration in normal plants (aboveground tissues) is $66 \mathrm{mg} / \mathrm{kg}$ (Outridge and Noller, 1991) and the toxic level is up to 230 $\mathrm{mg} / \mathrm{kg}$ (Borkert et al., 1998; Long et al., 2003). In this study, Zn concentrations in the shoots and roots of all sampling plants were 15.61$139.74 \mathrm{mg} / \mathrm{kg}$ and $30.1-124.18 \mathrm{mg} / \mathrm{kg}$, respectively, which were far lower than the phytotoxic range $(500-1500 \mathrm{mg} / \mathrm{kg}$ ) proposed by Chaney (1989). Ni is thought to have toxic effects on plants. According to Allen (1989), Ni concentrations in plants were poisonous over 5 $\mathrm{mg} / \mathrm{kg}$. In this study, the majority of Ni concentrations in shoots and roots were below $5 \mathrm{mg} / \mathrm{kg}$ except the value in the roots of C. pseudophragmites at Z2 unit ( $5.89 \mathrm{mg} / \mathrm{kg}$ ), indicating that Ni accumulated in intertidal plants might not lead toxic effect. Marsh plants can accumulate heavy metals through roots and/or shoots and generally present different pathways in the accumulation of metals between plants and surrounding environment (Bonanno and Giudice, 2010; Guilizzoni, 1991; Jackson et al., 1994; Markert, 1987). This study indicated that heavy metal concentrations differed between tissues and intertidal plants showed different patterns in metal absorption and internal transportation. The root tissues accumulated significantly greater 
Table 2

Comparison of heavy metal concentrations (means, $\mathrm{mg} / \mathrm{kg}$ ) in surface sediments found in intertidal zone of the northern Yellow River estuary and other estuaries or bays.

\begin{tabular}{|c|c|c|c|c|c|c|c|}
\hline Study area & $\begin{array}{l}\text { Study } \\
\text { period }\end{array}$ & $\mathrm{Pb}$ & $\mathrm{Cr}$ & $\mathrm{Cu}$ & $\mathrm{Zn}$ & $\mathrm{Ni}$ & References \\
\hline \multirow[t]{2}{*}{ Yellow River estuary, China } & 2009.5 & $43.05(35.8-51.7)$ & $44.09(35.9-54.7)$ & $22.85(15.6-29.9)$ & $54.12(38.2-68.3)$ & $22.97(17.6-28.4)$ & This study \\
\hline & 1995-1998 & 15 & NA & 30 & 100 & 35 & Zhang et al. (2001) \\
\hline \multirow[t]{2}{*}{ Yangtze estuary, China } & $2004.4-11$ & $(29.9-106.0)$ & $(27.8-82.7)$ & $(13.7-79.9)$ & $(68.1-419.1)$ & $(32.2-112.6)$ & Hu et al. (2013) \\
\hline & $2005.4-8$ & $27.3(18.3-44.1)$ & $78.9(36.9-173)$ & $30.7(6.87-49.7)$ & $94.3(47.6-154)$ & $38.1(17.6-48.0)$ & Zhang et al. (2009) \\
\hline Pearl River estuary, China & $2009.3-4$ & 79.27 & 109.70 & 65.36 & 244.42 & 50.56 & Zhang et al. (2010a) \\
\hline Bohai Bay, China & 2008.5 & $25.6(18.8-39.1)$ & $68.6(36.7-110)$ & $24.0(7.9-46.7)$ & $73.0(34.0-123)$ & $28.0(14.1-47.9)$ & Gao and Li (2012) \\
\hline Quanzhou Bay, China & 2006.11 & $67.7(34.3-100.9)$ & $82.0(51.1-121.7)$ & $71.4(24.8-119.7)$ & $179.6(105.5-241.9)$ & $33.4(16.1-45.7)$ & Yu et al. (2008) \\
\hline $\begin{array}{l}\text { New Territories of Hong } \\
\text { Kong, China }\end{array}$ & NA & 80 & 40 & 80 & 240 & 30 & Tam and Wong (2000) \\
\hline Kyeonggi Bay, Korea & $1992.7-8$ & $(33-83)$ & $(68-194)$ & $(70-323)$ & $(82-272)$ & $(144-249)$ & Ahn et al. (1995) \\
\hline Scheldt estuary, Belgium & NA & NA & NA & $82-132$ & $413-947$ & $32.2-53.8$ & Du Laing et al. (2008) \\
\hline Seine estuary, France & 2003.7-9 & $48(18-78)$ & NA & $29(3-45)$ & $123(53-188)$ & $27(18-43)$ & Cundy et al. (2005) \\
\hline \multirow[t]{2}{*}{ Medway estuary, UK } & & $65(46-138)$ & NA & $38(26-50)$ & $152(103-210)$ & $32(18-49)$ & \\
\hline & NA & 67 & 76 & 42 & 138 & 28 & Spencer (2002) \\
\hline
\end{tabular}

NA, not available; Values in bracket are the range of heavy metal concentrations.

concentrations of all five metals than shoots at $\mathrm{Z2}, \mathrm{Z3}$ and $\mathrm{Z} 4$ units (TFs $<1$ ), and this trend was also observed at $\mathrm{Z} 5$ (for $\mathrm{Pb}, \mathrm{Cr}, \mathrm{Ni}$ ), Z6 (for $\mathrm{Cr}, \mathrm{Cu}, \mathrm{Ni}$ ) and $\mathrm{Z7}$ (for $\mathrm{Cr}$ ) units (Fig. 8). Similar results were drawn by previous studies (Baldantoni et al., 2004; Cardwell et al., 2002; Fitzgerald et al., 2003; Kähkönen et al., 1997; Outridge and Noller, 1991). Root uptake with subsequent translocation to aboveground tissues has been reported as the main route of metal accumulation in many marsh plants (Jackson, 1998; Jackson et al., 1994), and this was tested in this study. As mentioned above, higher concentrations of heavy metal were measured in roots than those in shoots, which was probably due to the high availability of the substrate metals as well as their limited mobility from roots to the shoots once inside the plants (Baldantoni et al., 2004; Deng et al., 2004). For example, Pb is rather immobile in sediment and tends to be accumulated in roots, resulting in a scarce translocation into aboveground organs (Siedlecka et al., 2001). Also, there is no mobility of $\mathrm{Cr}$ from roots to the shoots and to the leaves (Kähkönen et al., 1997). The mobility of Ni in plants varies between species, from mobile in some plants (Thiesen and Blincoe, 1988; Tiffin, 1971 ) to immobile in others (Sajwan et al., 1996). The low mobility of these heavy metals might be due to barriers or to lack of transport mechanisms (Shewry and Peterson, 1974). By comparison, the shoot tissues of the plants at Z1, Z7 and Z8 units accumulated greater concentrations of heavy metal than roots (TFs $>1$ ), which was closely related to the corresponding BCFs. The BCFs of heavy metals in marsh plants could reflect the capability of the plants accumulated heavy metals from surrounding environment (Zhang et al., 2011). Higher BCFs of Cu and Zn than $\mathrm{Pb}, \mathrm{Cr}$ and $\mathrm{Ni}$ (Fig. 8) might be explained as the uptake of $\mathrm{Cu}$ and $\mathrm{Zn}$ with lower concentration by bio-tissues (Kabata-Pendias and Pendias, 2001; Yang et al., 2008). In this study, high TFs of heavy metals at Z1, Z7 and Z8 units generally occurred in coincide with high BCFs (Fig. 8), indicating that a fraction heavy metals accumulated from surrounding environment by plants was transported from roots to the shoots. Although the concentrations of heavy metal in surface sediments of Z1 and Z7 units were very low (Fig. 6), both BCFs and TFs were very high (Fig. 8). One possible explanation was that the metal absorption mechanisms of the plants at Z1 (S. minimum-P. supina community, S. minimum was dominant species) and Z7 (S. salsa-T. chinensis community, S. salsa was dominant species) units were different with those of the plants at other units. Many studies have reported that rooted species could absorb metals through their roots and rhizomes as well as through their leaves because the latter provided an expanded area to trap particulate matter, sorb metal ions, and accumulate and sequester pollutants (Bishop and DeWaters, 1988; Levine et al., 1990; Ward, 1987; Welsh and Denny, 1980). Guilizzoni (1991) also indicated that some rooted plants might absorb metals directly from water when they were not readily available in sediments and/or in high concentrations in surroundings. Based on these analyses, it was concluded that the plant leaves at Z1 unit might accumulate heavy metals directly from the Yellow River water since the metal concentrations in surface sediment were very low (Fig. 6) and the Z1 unit was frequently influenced by the Yellow river during the "water and sand regulation project" (WSRP) every year. The purpose of the WSRP was to increase the supply of freshwater and sediment for the Yellow River estuary by discharging the water in Xiaolangdi Reservoir and scouring the sediment in the reservoir and riverbed (Cui et al., 2009). During the WSRP (from June to July in each year), the river water frequently flooded the $\mathrm{Z} 1$ unit, which provided the possibility for the plants to absorb metals directly from the river water. Similarly, the plant leaves at Z7 unit might also accumulate heavy metals directly from seawater since the metal concentrations in surface sediment were very low (Fig. 6) and the $\mathrm{Z7}$ unit was frequently affected by the tidal fluctuation. Because Z8 unit was covered by pure $S$. salsa community and the metal concentrations in surface sediment were very high (Fig. 6), it ws concluded that higher TFs $(>1)$ and BCFs at Z8 unit might be dependent on both the mechanism of root uptake with subsequent translocation to shoots and the mechanism of leaf absorption from seawater. The two mechanisms might also coexisted in plants at $\mathrm{Z5}$ (for $\mathrm{Cu}$ and $\mathrm{Zn}, \mathrm{TFs}>1$ ) and $\mathrm{Z6}$ (for $\mathrm{Pb}$ and $\mathrm{Zn}, \mathrm{TFs}>1$ ) units due to the relatively high BCFs (Fig. 8) and the frequent influences of tidal fluctuation in middle marsh. Similar results were reported by previous studies. Welsh and Denny (1980) pointed out that in nine taxa of submersed aquatic macrophytes, $\mathrm{Pb}$ accumulation in shoots was the result of adsorption from water, while $\mathrm{Cu}$ accumulation was mainly due to absorption by roots, even if a direct adsorption form the water into the shoots could also occur. Campbell et al. (1985) reported that the Cu accumulated in the stem and rhizome of Nuphar variegatum probably originated from sediments, whereas $\mathrm{Zn}$ was mainly from the water column. However, it was very difficult to determine, in what proportion, an element was taken up from sediment by the roots of a plant or from water, directly by the shoots. Also, it is very difficult to establish the amount of an element that is transferred from roots to the shoots. For one thing, it certainly depended on the chemical behaviors of elements and also on sediment geochemistry (Baldantoni et al., 2004; Jackson, 1998). For another, different factors besides water and sediment, such as atmospheric dry and wet deposition onto leaf surfaces, seasonal physiology and species-specific capacities for uptake, translocation and compartmentalization of trace elements, might also contribute to the differential bioaccumulation (Bargagli, 1998; Ge et al., 2013; Song and Sun, 2014; Zhang et al., 2010b). It was reported that the soluble and insoluble fractions of heavy metals in wet and dry atmospheric deposition were greatly different (Morselli et al., 2003), and the soluble fraction was generally favorable for the absorption of plants (Wang and Yang, 2004). Thus, the proportions of dry and wet deposition or the fractions of soluble and insoluble heavy metals in atmospheric deposition, to some 
extent, might affect the distribution of heavy metals in intertidal sediments and the bioaccumulation capacities of different plants in the Yellow River estuary. Other climatic variables such as heavy rain and violent storm might also influence the bioaccumulation of heavy metals by affecting the physiological traits of plants and the redistribution of heavy metals in intertidal sediments under flooding or storm tide conditions (Song and Sun, 2014). Moreover, the bioaccumulation of heavy metals in the Yellow River estuary might also be affected by seasonal variations of plant physiology and species-specific capacities, which has been reported by Deng et al. (2004), and Song and Sun (2014). All these probabilities need to be clarified in the next step.

\subsection{Potential to use plants in bio-monitoring and phytoremediation}

As mentioned above, although the intertidal sediments in the Yellow River estuary were not contaminated by heavy metals, $\mathrm{Pb}$ and $\mathrm{Ni}$ at Z4, Z6 and Z9 units had high eco-toxic risk of exposure. Because the loading of heavy metals in the Yellow River estuary is increasing (State Oceanic Administration of China, 2013), intertidal sediments may be seriously contaminated if no effective meausres are taken to control the import of pollutants in the future. Thus, the use of biomonitors living and growing in intertidal zone could yield valuable information not only on the presence of anthropogenic stressors, but, more importantly, on the adverse influence the stressors are having on the environment (Chang et al., 2009; Ngayila et al., 2009). In this study, the plant tissues at Z1, $\mathrm{Z7}$ and $\mathrm{Z8}$ units accumulated more heavy metals than those at other units (Fig. 8), indicating that S. minimum-P. supina (Z1), S. salsaT. chinensis (Z7) and S. salsa (Z8) was more suitable for using as biological indicator while determining environmental pressures. In addition to biomonitor, phytoremediation may be applied to reduce, remove, degrade or immobilize intertidal pollutants. According to the different capacity for metal uptake, species able to accumulate relatively high metal concentrations in the aboveground tissues could be good candidates for phytoextraction (Deng et al., 2004). According to the present results, S. minimum-P. supina (Z1) and S. salsa (Z8) would be good candidates for extracting $\mathrm{Pb}, \mathrm{Cr}, \mathrm{Cu}, \mathrm{Zn}$ and $\mathrm{Ni}$, S. salsa-P. australis (Z5) for extracting $\mathrm{Cu}$ and $\mathrm{Zn}$, T. chinensis-S. salsa (Z6) for extracting $\mathrm{Pb}$ and $\mathrm{Zn}$, and S. salsaT. chinensis (Z7) for extracting $\mathrm{Cu}, \mathrm{Zn}$ and $\mathrm{Ni}$, from $\mathrm{Pb} / \mathrm{Cr} / \mathrm{Cu} / \mathrm{Zn}$ or Nicontaminated sediments, respectively. Other plants at Z2, Z3 and Z4 units, which have strong ability to reduce metal translocation from roots to shoots, are more suitable as phytostabilizers for revegetation of metal-contaminated sediment. In intertidal zone of the Yellow River estuary, S. salsa is the most prevalent halophytes and it has strong adaptations to environmental stresses (such as high salinity, flooding and sediment burial) (Han et al., 2005), and also, its abovegound and belowgound biomasses were 4.30 and 8.04-fold higher than those of S. minimum-P. Supina, respectively (Fig. 2), indicating that S. salsa had many advantages which made it an appropriate test species for all five heavy metals. Thus, when planning activities of biomonitor or phytoremediation in intertidal zone, the role of $S$. salsa should be seriouly considered.

\section{Acknowledgements}

The authors would like to acknowledge the financial support of the National Nature Science Foundation of China (No. 41371104, 41171424, 41101084, 41103073), the "1-3-5" Strategy Plan Program of the Yantai Institute of Coastal Zone Research of the Chinese Academy of Sciences (No. Y254021031) and the Key Research Program of the Chinese Academy of Sciences (No. KZZD-EW-14).

\section{References}

Ahn, I.Y., Kang, Y.C., Choi, J., 1995. The influence of industrial effluents on intertidal benthic communities in Panweol, Kyeonggi Bay (Yellow Sea) on the west coast of Korea. Mar. Pollut. Bull. 30, 200-206.
Allen, S.E., 1989. Chemical analysis of ecological material, 2nd edition. Blackwell Scientific Publications, Oxford.

Arias, H.R., Saucedo, R.A., Wood, K., Nunez, A., Jimenez, J., 2005. Metal contamination of a riparian area in the Conchos watershed of Chihuahua, Mexico. Water Resour. Manag. 80, 269-275.

Armitage, P.D., Bowes, M.J., Vincent, H.M., 2007. Long-term changes in macroinvertebrate communities of a heavy metal polluted stream: the river Nent (Cumbria, UK) after 28 years. River Res. Appl. 23 (9), 997-1015.

Baldantoni, D., Alfani, A.D., Tommasi, P., Bartoli, G., Virzo, D., Santo, A., 2004. Assessment of macro and microelement accumulation capability of two aquatic plants. Environ. Pollut. 130, 149-156.

Bargagli, R., 1998. Trace elements in terrestrial plants. An ecophysiological approach to biomonitoring and biorecovery. Springer, Berlin, p. 324.

Bishop, P.L., DeWaters, J., 1988. Biotechnology for degradation of toxic chemicals in hazardous wastes. Noyes Data Corp, Park Ridge, NJ.

Bockheim, J.G., 2005. Soil endemism and its relation to soil formation theory. Geoderma 129 (3-4), 109-124.

Bonanno, G., Giudice, R.L, 2010. Heavy metal bioaccumulation by the organs of Phragmites australis (common reed) and their potential use as contamination indicators. Ecol. Indic. 10, 639-645.

Borkert, C.M., Cox, F.R., Tucker, M.R., 1998. Zinc and copper toxicity in peanut, soybean, rice and corn in soil mixtures. Commun. Soil Sci. Plant 29, 2991-3005.

Breslin, V.T., Sanudo-Wilhelmy, S.A., 1999. High spatial resolution sampling of metals in the sediment and water column in Port Jefferson Harbor, New York. Estuaries 22, 669-680.

Calmano, W., Hong, J., 1993. Binding and mobilization of heavy metal in contaminated sediment affected by the $\mathrm{PH}$ and redox potential. Water Sci. Technol. 28, 223-235.

Campbell, P.G.C., Tessier, A., Bisson, M., Bougie, R., 1985. Accumulation of copper and zinc in the yellow water lily, Nuphar variegatum: relationships to metal partitioning in the adjacent lake sediments. Can. J. Fish. Aquat. Sci. 42, 23-32.

Cardwell, A.J., Hawker, D.W., Greenway, M., 2002. Metal accumulation in aquatic macrophytes from southeast Queensland, Austrilia. Chemosphere 48, 653-663.

Chaney, R.L., 1989. Toxic element accumulation in soils and crops: protecting soil fertility and agricultural food chains. In: Bar-Yosef, B., Barrow, N.J., Goldshmid, J. (Eds.), Inorganic contaminants in the Vadose Zone. Springer-Verlag, Berlin, pp. 140-158.

Chaney, R.L., Malik, M., Li, Y.M., Brown, S.L., Brewer, E.P., Angle, J.S., Baker, A.J.M., 1997. Phytoremediation of soil metals. Curr. Opin. Biotechnol. 8, 279-284.

Chang, J., Liu, G.H., Liu, Q.S., 2004. Analysis on spatio-temporal feature of coastline change in the Yellow River estuary and its relation with runoff and sand-transportation. Geogr. Res. 23 (5), 339-346.

Chang, J.S., Yoon, I.H., Kim, K.W., 2009. Heavy metal and arsenic accumulating fern species as potential ecological indicators in As-contaminated abandoned mines. Ecol. Indic. 9, 1275-1279.

Comans, R.N.J., van Dijk, C.P.., 1988. Role of complexation process in cadmium mobilization during estuarine mixing. Nature 336, 151-154.

Cui, B.S., Yang, Q.C., Yang, Z.F., Zhang, K.J., 2009. Evaluating the ecological performance of wetland restoration in the Yellow River Delta, China. Ecol. Eng. 35, 1090-1103.

Cundy, A.B., Hopkinson, L., Lafite, R., Spencer, K., Taylor, J.A., Ouddane, B., Heppell, C.M., Carey, P.J., Charman, R.O., Shell, D., Ullyott, J.S., 2005. Heavy metal distribution and accumulation in two Spartina sp.-dominated macrotidal salt marshes from the Seine estuary (France) and the Medway estuary (UK). Appl. Geochem. 20 (6), 1195-1208.

Demirezen, D., Aksoy, A., 2004. Accumulation of heavy metals in Typha angustifolia (L.) and Potamogeton pectinatus (L.) living in Sultan Marsh (Kayseri, Turkey). Chemosphere 56, 685-696.

Deng, H., Ye, Z.H., Wong, M.H., 2004. Accumulation of lead, zinc, copper and cadmium by 12 wetland plant species thriving in metal-contaminated sites in China. Environ. Pollut. 132, 29-40.

Deng, L.P., Zhu, X.B., Wang, X.T., Oin, J., 2008. Granularity distribution of the suspended particles and adsorption of $\mathrm{Cu}^{2+}$ from the lower reaches of the Yellow River during flood seasons. Mar. Sci. 32 (3), 19-24.

Dong, H.F., Yu, J.B., Sun, Z.G., Mou, X.J., Chen, X.B., Mao, P.L., Wu, C.F., Guan, B., 2010. Spatial distribution characteristics of organic carbon in the soil-plant systems in the Yellow River estuary tidal flat wetland. Environ. Sci. 31 (6), 1594-1599.

Du Laing, G., De Vos, R., Vandecasteele, B., Lesage, E., Tack, F.M.G., Verloo, M.G., 2008. Effect of salinity on heavy metal mobility and availability in intertidal sediments of the Scheldt estuary. Estuar. Coast. Shelf Sci. 77 (4), 589-602.

Du Laing, G., Rinklebe, J., Vandecasteele, B., Meers, E., Tack, F.M., 2009. Trace metal behaviour in estuarine and riverine floodplain soils and sediment: A review. Sci. Total Environ. 407 (13), 3972-3985.

Fitzgerald, E.J., Caffrey, J.M., Nesaratnam, S.T., McLoughlin, P., 2003. Copper and lead concentrations in salt marsh plants on the Suir Estuary. Irel. Environ. Pollut. 123, $67-74$

Flegal, A.R., Smith, G.J., Gill, G.A., Sañudo-Wilhelmy, S., Anderson, L.C.D., 1991. Dissolved trace element cycles in the San Francisco Bay estuary. Mar. Chem. 36, 329-363.

Fürtig, K., Pavelic, D., Brunold, C., Brändle, R., 1999. Copper-and-iron induced injuries in roots and rhizomes of reed (Phragmites australis). Limnologica 29, 60-63.

Gao, X.L., Li, P.M., 2012. Concentration and fractionation of trace metals in surface sediments of intertidal Bohai Bay, China. Mar. Pollut. Bull. 64, 1529-1536.

Ge, Y.S., Cao, Y.L., Zeng, C.H., Li, Z.Q. Wang L., 2013. Monitoring heavy metal pollutions in Chengdu atmosphere using terrestrial bryophytes. Ecol. Environ. Sci. 22 (5), 844-850.

Griscom, S.B., Fisher, N.S., Luoma, S.N., 2000. Geochemical influences on assimilation of sediment-bound metals in clams and mussels. Environ. Sci. Technol. 34, 91-99.

Guilizzoni, P., 1991. The role of heavy metals and toxic materials in the physiological ecology of submersed macrophytes. Aquat. Bot. 41, 87-109.

Han, N., Shao, Q., Lu, C.M., Wang, B.S., 2005. The leaf tonoplast V-H ${ }^{+}$-ATPase activity of a $\mathrm{C}_{3}$ halophyte Suaeda salsa is enhanced by salt stress in a Ca-dependent mode. J. Plant Physiol. 162, 267-274. 
Hu, X.F., Du, Y., Feng, J.W., Fang, S.Q., Gao, X.J., Xu, S.Y., 2013. Spatial and seasonal variations of heavy metals in wetland soils of the tidal flats in the Yangtze estuary, China: Environmental implications. Pedosphere 23 (4), 511-522.

Jackson, L.J., 1998. Paradigms of metal accumulation in rooted aquatic vascular plants. Sci. Total Environ. 219, 223-231.

Jackson, L.J., Rowan, D.J., Cornett, R.J., Kalff, J., 1994. Myriophyllum spicatum pumps essential and nonessential trace elements from sediments to epiphytes. Can. J. Fish. Aquat. Sci. $51,1769-1773$.

Kabata-Pendias, A., Pendias, H., 2001. Trace elements in soils and plants, 3rd ed. CRC Press, Boca Raton, F.L.

Kähkönen, M.A., Pantsar-Kallio, M., Manninen, P.K.G., 1997. Analysing heavy metal concentrations in the different parts of Elodea Canadensis and surface sediment with PCA in two boreal Lakes in Southern Finland. Chemosphere 35, 2645-2656.

Levine, S.N., Rudnick, D.T., Kelly, J.R., Morton, R.D., Buttel, L.A., 1990. Pollution dynamics as influenced by seagrass beds: experiments with tributyltin in Thalassia microcosms. Mar. Environ. Res. 30, 297-322.

Li, Y.F., Huang, Y.L., Li, S.K., 1991. A primarily analysis on the coastal physiognomy and deposition of the modern Yellow River Delta. Acta Oceanol. Sin. 13 (5), 662-671.

Li, Q.S., Liu, Y.N., Du, Y.F., Cui, Z.H., Shi, L., Wang, L.L., Li, H.J., 2011. The behavior of heavy metals in tidal flat sediments during fresh water leaching. Chemosphere 82 (6), 834-838.

Long, X.X., Yang, X.E., Ni, W.Z., Ye, Z.Q., He, Z.L., Calvert, D.V., Sftoffella, J.P., 2003. Assessing zinc thresholds for phytoxicity and potential dietary toxicity in selected vegetable crops. Commun. Soil Sci. Plant 34, 1421-1434.

Markert, B., 1987. Interelement correlations in plants. Fresenius J. Anal. Chem. 329, 462-465.

Mistch, W.J., Gosselink, J.G., Anderson, C.J., Zhang, L., 2009. Wetland ecosystems. John Wiley \& Sons, Inc., Hoboken, New Jersey.

Moran, S.B., Yeats, P.A., Balls, P.W., 1996. On the role of colloids in trace metal solidsolution partitioning in continental shelf waters: a comparison of model results and field data. Cont. Shelf Res. 16, 397-408.

Morselli, L., Olivieri, P., Brusori, B., Passarini, F., 2003. Soluble and insoluble fractions of heavy metals in wet and dry atmospheric depositions in Bologna, Italy. Environ. Pollut. 124, 457-469.

Mou, X.J., 2010. Study on the nitrogen biological cycling characteristics and cycling model of tidal wetland ecosystem in Yellow River estuaryMaster degree dissertation Yantai Institute of Coastal Zone Research. Chinese Academy of Sciences, Yantai.

Ngayila, N., Botineau, M., Baudu, M., Basly, J.P., 2009. Myriophyllum alterniflorum DC. Effect of low concentrations of copper and cadmium on somatic and photosynthetic endpoints: a chemometric approach. Ecol. Indic. 9, 307-312

Outridge, P.M., Noller, B.N., 1991. Accumulation of toxic trace elements by freshwater vascular plants. Rev. Environ. Contam. Toxicol. 121, 1-63.

Peng, K.J., Luo, C.L., Lou, L.Q., Li, X.D., Shen, Z.G., 2008. Bioaccumulation of heavy metals by the aquatic plants Potamogeton pectinatus L. and Potamogeton malaianus Miq. and their potential use for contamination indicators and in wastewater treatment. Sci. Total Environ. 392, 22-29.

Prokisch, J., Széles, É., Kovács, B., Györi, Z., Németh, T., West, L., Harper, S., Adriano, D., 2009. Sampling strategies for testing and evaluation of soil contamination in riparian system at the Tisza River Basin, Hungary. Commun. Soil Sci. Plant 40 (1-6), 391-406.

Rae, J.E., 1997. Trace metals in deposited intertidal sediments. In: Jickells, T.D., Rae, J.E. (Eds.), Biogeochemistry of intertidal sediments. Cambridge University Press, Cambridge, pp. 16-31.

Ross, S.M., 1994. Source and forms of potentially toxic metals in soil-plant systems. In: Ross, S.M. (Ed.), Toxic metals in soil-plant system. John Wiley \& Sons, Chichester, pp. 3-25.

Sajwan, K.S., Ornes, W.H., Youngblood, T.V., Alva, A.K., 1996. Uptake of soil applied cadmium, nickel and selenium by bush beans. Water Air Soil Pollut. 91, 209-217.

Sakan, S., Dordević, D.S., Manojlović, D.D., Predrag, P.S., 2009. Assessment of heavy metal pollutants accumulation in the Tisza river sediments. J. Environ. Manag. 90 (11) 3382-3390.

Shewry, P.R., Peterson, P.J., 1974. The uptake and transport of chromium by Barley seedlings (Hordeum vulgare L.). Planta 132, 209-214.

Siedlecka, A., Tukendorf, A., Skórzyńska-Polit, E., Maksymiec, W., Wójcik, M., Baszyński, T., Krupa, Z., 2001. Angiosperms (Asteraceae, Convolvulaceae, Fabaceae and Poaceae; other than Brassicaceae). In: Prasad, M.N.V. (Ed.), Metals in the environmentAnalysis by Biodiversity. Marcel. Dekker, Inc., New York, pp. 171-217.

Song, H.L., Sun, Z.G., 2014. Temporal variations and bioaccumulation of heavy metals in different Suaeda salsa marshes of the Yellow River estuary, China. Environ. Sci. Pollut. Res. http://dx.doi.org/10.1007/s11356-014-3296-7 (Published online: 25 July 2015).

Song, C.Y., Huang, C., Liu, Q.S., Liu, G.H., 2010. Simulation for Suaeda heteroptera potential distribution in the Yellow River Delta by using generalized additive models. J. Nat. Resour. 25 (4), 677-685.

Spencer, K.L., 2002. Spatial variability of metals in the inter-tidal sediments. Mar. Pollut. Bull. 44, 933-944.
State Oceanic Administration of China, 2011. Ocean Environmental Quality Communique of China in 2010. http://www.coi.gov.cn/gongbao/huanjing/201107/t20110729_ 17486.html.

State Oceanic Administration of China, 2012. Ocean Environmental Quality Communique of China in 2011. http://www.coi.gov.cn/gongbao/huanjing/201207/t20120709 23185.html.

State Oceanic Administration of China, 2013. Ocean Environmental Quality Communique of China in 2012. http://www.coi.gov.cn/gongbao/huanjing/201304/t20130401 26428.html.

Sun, W.L., Sun, Z.G., Mou, X.J., Wang, L.L., 2010. Distribution characteristics of phosphor and sulfur in different wetland soils of the Yellow River Delta. Bull. Soil Water Conserv. 30 (4), 104-108.

Sun, Z.G., Mou, X.J., Song, H.L., Jiang, H.H., 2013. Sulfur biological cycle of the different Suaeda salsa marshes in the intertidal zone of the Yellow River estuary, China. Ecol. Eng. 53, 153-164.

Tam, N.F.Y., Wong, Y.S., 2000. Spatial variation of heavy metals in surface sediments of HongKong mangrove swamps. Environ. Pollut. 110, 195-205.

Tang, A.K., Liu, R.H., Ling, M., Xu, L.Q., Wang, J.Y., 2010. Distribution characteristics and controlling factors of soluble heavy metals in the Yellow River estuary and adjacent sea. Procedia Environ. Sci. 2, 1193-1198.

The Committee of Agro-chemistry of the Chinese Society of Soil Science, 1983. The conventional analysis methods in soil agro-chemistry. Science Press, Beijing.

Thiesen, M.O., Blincoe, C., 1988. Isolation and partial characterisation of nickel complexes in higher plants. Biol. Trace Elem. Res. 16, 239-252.

Tian, J.Y., Wang, X.F., Cai, X.J., 2005. Protection and restoration technique of wetland ecosystem in Yellow River Delta. China Ocean University Press, Qingdao.

Tiffin, L.O., 1971. Translocation of nickel xylem exudate of plants. Plant Physiol. 48, 273-277.

Turner, A., 2000. Trace metal contamination in sediments from UK Estuaries: an experimental evaluation of the role of hydrous iron and manganese oxides. Estuar. Coast. Shelf Sci. 50, 355-371.

U.S. Environmental Protection Agency, 1996. ECO update: ecotox thresholds. Office of Emergency and Remedial Response, EPA. 540/F-95/038. Intermittent Bulletin vol. $3(2)$.

Wang, Z.L., Liu, C.Q., 2003. Distribution and partition behavior of heavy metals between dissolved and acid-soluble fractions along a salinity gradient in the Changjiang Estuary, eastern China. Chem. Geol. 202, 383-396.

Wang, X.F., Yang, Y.Q., 2004. Progresses in research on speciation and bioavailability of heavy metals in soil-plant system. Environ. Prot. Chem. Ind. 24 (1), 24-27.

Wang, Y., Liu, R.H., Fang, D.J., Yu, P., Wang, J.Y., Tang, A.K., 2013. Distribution and accumulation characteristics of heavy metals in sediments in southern sea area of Huludao City, China. Chin. Geogr. Sci. 23 (2), 194-202.

Ward, T.J., 1987. Temporal variation of metals in the seagrass Posidonia australis and its potential as a sentinel accumulator near a lead smelter. Mar. Biol. 95, 315-321.

Welsh, R.P.F., Denny, P., 1980. The uptake of lead and copper by submerged aquatic macrophytes in two English lakes. J. Ecol. 68, 443-455.

Williams, T.P., Bubb, J.M., Lester, J.N., 1994. Metal accumulation within saltmarsh environment: a review. Mar. Pollut. Bull. 28, 277-290.

Xu, S.Y., Tao, J., Chen, Z.L., Chen, Z.Y., Lu, Q.Y., 1997. Dynamic accumulation of heavy metals in intertidal sediments of Shanghai. Oceanol. Limnol. Sin. 28, 509-515.

Xu, X.G., Guo, H.H., Chen, X.L., Lin, H.P., Du, Q.L., 2002. A multi-scale study on land use and land cover quality change: the case of the Yellow River Delta in China. GeoJournal 56 (3), 177-183.

Yang, S.L., 1999. Sedimentation on a growing intertidal island in the Yangtze River mouth. Estuar. Coast. Shelf Sci. 49, 401-410.

Yang, H.J., Shen, Z.M., Zhu, S.H., Wang, W.H., 2008. Heavy metals in wetland plants and soil of Lake Taihu, China. Environ. Toxicol. Chem. 27 (1), 38-42.

Yu, R.L., Yuan, X., Zhao, Y.H., Hu, G.R., Tu, X.L., 2008. Heavy metal pollution in intertida sediments from Quanzhou Bay, China. J. Environ. S. 20, 664-669.

Zhang, W., Yu, L., Hutchinson, S.M., Xu, S., Chen, Z., Gao, X., 2001. China's Yangtze Estuary: I. Geomorphic influence on heavy metal accumulation in intertidal sediments. Geomorphology 41, 195-205.

Zhang, W.G., Feng, H., Chang, J.N., Qu, J.G., Xie, H.X., Yu, L.Z., 2009. Heavy metal contamination in surface sediments of Yangtze Rive intertidal zone: An assessment from different indexes. Environ. Pollut. 157, 1533-1543.

Zhang, H.G., Cui, B.S., Xiao, R., Zhao, H., 2010a. Heavy metals in water, soils and plants in riparian wetlands in the Pearl River Estuary, South China. Procedia Environ. Sci. 2, 1344-1354.

Zhang, M.K., Liu, Z.Y., Zhou, C., 2010b. Effect of atmospheric deposition on heavy metal accumulation in vegetable crop near a lead-zinc smelt mine. J. Zhejiang Univ. (Agric Life Sci.) 36 (2), 221-229.

Zhang, H.G., Cui, B.S., Zhang, K.J., 2011. Heavy metal distribution of natural and reclaimed tidal riparian wetlands in south estuary, China. J. Environ. Sci. 23 (2), 1937-1946. 